NBER WORKING PAPER SERIES

\title{
FAITH-BASED CHARITY AND CROWD OUT DURING THE GREAT DEPRESSION
}

\author{
Jonathan Gruber \\ Daniel M. Hungerman \\ Working Paper 11332 \\ http://www.nber.org/papers/w11332
}

\author{
NATIONAL BUREAU OF ECONOMIC RESEARCH \\ 1050 Massachusetts Avenue \\ Cambridge, MA 02138 \\ May 2005
}

We are grateful to participants at the MIT public finance lunch, the Sloan Marketing Seminar, the Applied Microeconomics Seminar at Columbia, and the SSRC capstone conference on non-profits and philanthropy for helpful comments, and to Jocelyn D'Arcy, Ariel Edelstein, George Lam, Christopher Lee, Matthew Levy, Bert Lue, Benjamin North, Phillip Neuhart, Eechen Ong, Naakorkoi Pappoe, Dipan Patel, Juliana Perez, Joanna Shen, Ira Simkhovitch, Aek Thimton, Anthony Tse, Constantinos Tsoucalas, Jonathan Ursprung, Jennifer Wong, and James Xenakis for excellent assistance in creating the data for this project. Price Fishback, Shawn Kantor, John Wallis, and the Southern Baptist Historical Library and Archives also provided data. Hungerman acknowledges financial support from the NBER. The views expressed herein are those of the author(s) and do not necessarily reflect the views of the National Bureau of Economic Research.

(C)2005 by Jonathan Gruber and Daniel M. Hungerman. All rights reserved. Short sections of text, not to exceed two paragraphs, may be quoted without explicit permission provided that full credit, including (C) notice, is given to the source. 
Interperting the Evidence on Life Cycle Skill Formation

Jonathan Gruber and Daniel M. Hungerman

NBER Working Paper No. 11332

May 2005

JEL No. H3, N4

\begin{abstract}
$\underline{\text { ABSTRACT }}$
Interest in religious organizations as providers of social services has increased dramatically in recent years. Churches in the U.S. were a crucial provider of social services through the early part of the twentieth century, but their role shrank dramatically with the expansion in government spending under the New Deal. In this paper, we investigate the extent to which the New Deal crowded out church charitable spending in the 1930s. We do so using a new nationwide data set of charitable spending for six large Christian denominations, matched to data on local New Deal spending. We instrument for New Deal spending using measures of the political strength of a state's congressional delegation, and confirm our findings using a different instrument based on institutional constraints on state relief spending. With both instruments we find that higher government spending leads to lower church charitable activity. Crowd-out was small as a share of total New Deal spending (3\%), but large as a share of church spending: our estimates suggest that church spending fell by $30 \%$ in response to the New Deal, and that government relief spending can explain virtually all of the decline in charitable church activity observed between 1933 and 1939.

\author{
Jonathan Gruber \\ MIT Department of Economics \\ E52-355 \\ 50 Memorial Drive \\ Cambridge, MA 02142-1347 \\ and NBER \\ Daniel M. Hungerman \\ Duke University \\ danh@econ.duke.edu
}

gruberj@mit.edu
\end{abstract}


Recent years have seen increased interest in religious organizations as providers of social services. Starting with the passage of "charitable choice" legislation in the 1990s and continuing with the establishment of Faith-Based and Community Initiatives Centers throughout the executive branch of the Federal government, policy makers have dramatically increased the opportunity for church-state cooperation in aiding the poor. Part of the impetus behind this policy trend is the argument, advocated by individuals such as the influential Marvin Olasky (1992), that the current welfare state is inferior to the relief services historically offered by churches and other private organizations. As Olasky writes, "Isn't it time we realized that there is only so much that public policy can do?...Isn't it time to realize that only a richness of spirit can battle a poverty of soul?" (page 232).

It is certainly true that churches and other faith-based charities played a larger role in the past than they do today, in particular compared to the size of government. In 1926, congregations spent over \$150 million on projects other than church maintenance and upkeep (Bureau of the Census, 1930). That same year state governments spent \$23 million and local governments spent \$37 million on programs the Census Bureau identified as charitable in nature, and relief spending undertaken by the Federal government was negligible. ${ }^{1}$ Yet church charitable activity fell dramatically starting in the early 1930s, at the same time that the role of the government grew through the New Deal. This raises the central question of whether the growth in government social service provision "crowded out" charitable activity by churches.

We know very little, however, about the interaction between public sector spending and church benevolence, either during the depression or today. Indeed, this uncertainty extends to the larger literature on the crowd out of private charitable contributions by government activity. Despite theoretical and laboratory results suggesting that crowd out should be large, the empirical literature on crowd out yields a wide variety of estimates, most close to zero.

\footnotetext{
${ }^{1}$ These government activities include expenditures on outdoor poor relief, poor institutions, temporary homes for women and girls, care for children, care for the blind, deaf, and mute, and other charitable spending. The state data come from table 11 of Bureau the Census (1927) and the city data come from table 12 of Bureau the Census (1928).
} 
In this paper, we directly model the impact of government spending on church charitable activity, with two goals: to understand specifically how the government interacts with church benevolence, and to provide more generally a convincing estimate of the extent of crowd out in one sector. To do so, we investigate the extent of crowd out of charitable church spending by government relief spending during the Great Depression. This is a particularly interesting era to analyze both because of the crucial role that historical faith-based charity plays in current policy debates, and because the New Deal represented an extraordinary expansion in the role of government, as public-aid expenditures increased more than sixfold from 1933 to 1939 (National Resources Planning Board, 1942).

A difficulty in such an analysis is that the New Deal was a response to changing economic conditions. It may be the recession, not the New Deal, which led churches to contribute less. We therefore propose an empirical strategy based on two insights. The first is that there exists for a number of major Christian denominations church yearbook data that detail church benevolent activity not only nationally, but locally as well. We use these data to build a data set of church charitable activity by state and year from 1929 to 1939 for six of the largest Christian denominations of this era, which represented more than $20 \%$ of all churches at the time. We also use data from the Census of Religious Bodies, a national, multi-faith, decennial survey covering the vast majority of all religious adherents in the country. We match both of these data sets to information on New Deal-related relief spending by state and year.

The second insight is that there is a natural instrumental variables strategy which can allow us to disentangle the causal role of government spending on church charitable activity: using changes in the political power of state congressional delegations over this period. Following Anderson and Tollison (1991) and Couch and Shughart (1998), we consider the tenure of a state's representative on the House Appropriations Committee as a predictor of New Deal relief spending. Changes over time in that tenure, after the New Deal is in place relative to before, are exogenous predictors of the distribution of New Deal spending.

We find strong evidence that the rise in New Deal spending led to a fall in church charitable activity. Our central estimate suggests that each dollar of government relief spending in a state led to 
three cents less church spending. This is a small level of crowd out in dollar terms, but it is large in proportional terms, since church spending at the start of this period amounted to only $10 \%$ of the ultimate size of the New Deal. Relative to this baseline, there was a crowd out of at least 30\%, which can explain all of the time series decline in church benevolence over this period.

These results are not driven by any particular denomination, and they are robust to a number of different tests and specifications. Most strikingly, the results are also significant (and somewhat larger) using a completely different instrumental variables strategy, based on the fact that similar states often faced very different constitutional restrictions when financing relief. These restrictions may have affected states' abilities to exploit the matching properties inherent in many New Deal relief programs, again creating a plausibly exogenous source of variation in relief spending.

Our paper proceeds as follows. Section I provides background on the role of the church as a provider of benevolent activities, and past literature on crowd out. Section II discuses our data, and Section III focused on our empirical strategy. Section IV presents our basic results, while Section V presents a host of sensitivity checks. Section VI concludes.

\section{Section I: Background}

The Church as a Provider of Charitable Activity

Charitable church activity has played an important role throughout much of American history. ${ }^{2}$ The philanthropic role of churches was somewhat limited in colonial times (Cnaan, Wineburg, and Boddie, 1999). But after the Revolutionary War, a large influx of immigrants led to a proliferation of churches that provided social services to their respective ethnic groups (Cnaan et. al., 2002). Large revival movements in the early 1800s further increased interactions between religious proselytizers and the needy; this in turn led to new opportunities for church-based philanthropic work (Katz, 1996). The “Social Gospel” movement, a term first used in 1886, galvanized many churchgoers to actively address

\footnotetext{
${ }^{2}$ Since data for our project were only available for Christian denominations, we use the shorthand of churches when discussing religious organizations in general.
} 
various social problems (Cnaan, Wineburg, and Boddie, 1999). By the early twentieth century, charitable church activity played a "vital” role in helping the needy, and church social work included a wide variety of activities, such as employment services, hospital visitation, cooperation with government correctional and medical institutions and other social service agencies, advocacy for social causes, educational services such as job training and basic hygienic instruction, and various programs to aid the poor (Johnson, 1930).

In recent years, church social service provision has been dwarfed by the role of the government in the U.S. But there is a large literature that illustrates the important role churches continue to play as social service providers. Hodgkinson, Weitzman, and Kirsch (1988), Dudely and Rosen (2001), Cnann et. al. (2002) and Wuthnow (2004) all suggest that 80-90\% of churches are actively engaged in providing social services to the community. There is no work, however, examining the earlier era of the U.S. when churches played a larger role in social service provision; nor is there any work examining the role of government expansion in bringing about the end of that era.

\section{The Importance of Crowd Out}

Why do we care whether churches and government are substitutes? One important reason to care is claims that churches may be superior providers of charitable activity (e.g., Olasky, 1992). But there is little quantitative evidence on the benefits of faith-based social service provision, and even less evidence on whether churches and the government actually provide substitutable services. The only paper that directly assesses the substitutability of public social service spending for church spending is Hungerman (forthcoming). His paper estimates the response of one Christian denomination to the cutbacks in welfare for immigrants in the 1990s. He finds evidence of substitutability, with each one dollar in reduced welfare spending leading to 20 to 38 cents more in church spending. This finding is suggestive, but it applies only to one denomination responding to a very particular change in government policy, so its broader applicability is unclear. 
Another reason to care about church-state substitutability is that this analysis can provide a general insight into the crowd out of private charitable contributions by government activity. There is a sizeable literature on the crowd out of private charitable activity by the public sector, but this literature has produced very mixed results; see Steinberg (1991) for an excellent review. Some of the articles in this literature have focused on the effect of direct government grants to a charitable organization on donations to that organization (e.g. Kingma, 1989; Khanna, Posnett and Sandler, 1995; Payne, 1998; Okten and Weisbrod, 2000; Khanna and Sandler, 2000; Straub, 2004). Others have focused on the effect of general government transfer spending on charitable donations (e.g. Reece, 1979; Abrams and Schmitz, 1984; Lindsey and Steinberg, 1990). Most of these articles find either no crowd out of government transfers, or even crowd-in, with higher government transfers leading to more private donations. A few estimate larger crowd-out effects, with Payne's estimate of $50 \%$ crowd out at the upper end of these findings.

The lack of evidence for crowd-out contrast strongly with theoretical results suggesting large crowd out (e.g. Roberts, 1984; Bergstrom, Blume and Varian, 1986), as well as with experimental evidence that shows large (but still incomplete) crowd out in laboratory settings (Andreoni, 1993). The reason for this contrast may be that the articles in the crowd-out literature to date have not dealt effectively with the joint determination of government transfers and private contributions. At the level of the individual non-profit, it is natural to think that government transfers and private contributions are jointly determined. Charities which are particularly successful at fund-raising may be able to garner more funds from both sources; this may bias downwards estimates of crowd-out.

Some past research has tried to overcome this joint-determination problem by using general government transfers, either as an instrument at the level of the non-profit (Payne, 1998; Khanna and Sandler, 2000) or in a general model of charitable contributions. Some studies use time series variation in the size of government or government transfers (Khanna and Sandler, 2000; Abrams and Schmitz, 1984), while others use variation in social welfare spending across states (Reece, 1979; Payne, 1998). Neither of these is likely to be exogenous to individual donative behavior. Time series factors, such as the state of 
the economy or the distribution of income, will affect both government spending and individual donations. Similarly, variation across states in welfare spending will be driven by economic factors that might also determine individual giving.

Thus, the contradiction between the large crowd-out predictions of theory and the lack of crowdout evidence in the empirical literature may be due to identification problems with this literature. While our paper is focused on only one aspect of private charitable behavior, church benevolent expenditures, our findings are well-identified and have broader implications for the debate over crowd out.

One other study deserves special mention in our context: Roberts (1984) uses national data on city-level private relief expenditures to document a dramatic fall in those expenditures as government spending rose under the New Deal. But this evidence is not compelling, given that prior to 1933 this data set's measure of private spending includes funds given from public sources to private agencies (Fishback, Haines, Kantor, 2002). The Federal Emergency Relief Administration (FERA) mandated in August 1933 that public funds be administered by public agencies, creating a mechanical crowd-out effect in Roberts' data (Winslow, 1937). Our data come from churches, which are not included in Roberts' data (Baird and Lynch, 1942). We are therefore able to avoid the mechanical crowd out that drives Roberts’ result.

\section{Section II: Data}

\section{Church Benevolent Activity}

For our analysis of charitable spending by churches, we constructed a new data set of information on church benevolent activity by state and year over the 1929 to 1939 period. Our primary resource for doing so was the yearbooks available by a number of the major Christian denominations each year. We chose for our analysis any of the largest denominations which reported annual data at the state level (or at a finer level of detail that could be aggregated up to states) over the 1929 to 1939 period. Our final sample consists of six denominations: Congregational Christian Churches (according to the 1926 Census of Religious Bodies, this was the $11^{\text {th }}$ largest denomination in the country in 1926), the Lutheran Church- 
$\left(15^{\text {th }}\right)$, the Presbyterian Church in the USA $\left(5^{\text {th }}\right)$, and Southern Baptist Churches $\left(3^{\text {rd }}\right)$. Table 1 provides some basic information on each denomination.

To gather these data, we used all relevant elements of financial reporting in yearbooks published by each of these denominations. The unit of analysis consists of all the churches in a given denomination, in a given state.

Appendix A provides details on the source of the data for each denomination, and mentions denomination-specific issues related to gathering this information. The most important issue when collecting the data was the fact that some denominations reported information aggregated not by state but by some other denomination-specific area (such as a presbytery). In such cases we collected data on whether these areas crossed state lines, and any multi-state area which did not have at least $80 \%$ of its churches in a particular state was omitted. A second issue is that there were a few mergers during this time period involving our denominations, but these mergers were minor. Appendix A discusses these issues on a denomination-by-denomination basis.

There are two primary limitations of this data source. First, our key measure of charitable church activity is all church spending beyond local operating expenditures and upkeep, hereafter benevolences. There are a number of types of spending that benevolences subsume, including but not limited to local charitable spending. Second, our data exclude some of the largest denominations, most notably the Catholic Church, which does not provide national yearbook data on church benevolence. This raises the important question of the representativeness of our set of denominations for the overall amount of church charitable activity in the U.S.

To address both of these issues, we use data collected by the national Census of Religious Bodies. This survey, carried out in both 1926 and 1936, collected information on membership, number of congregations, and some financial information for a broad cross-section of religious denominations in the United States. These surveys represented the last installments in a general series of religious data collected by the census at varying intervals from 1850 through 1936. The surveys were national and multi faith, and contained information on the great majority of all adherents in the country. However, the 
last survey, in 1936, suffered from lower levels of cooperation and is generally regarded as less reliable than preceding censuses.

In Table 2, we use data from the 1926 and 1936 censuses to compare our set of denominations to the entire set of denominations collected. As panel A of the table shows, our set of six denominations represent $20 \%$ of churches and $15 \%$ of members in 1936 , and $23 \%$ of churches and $17 \%$ of members in 1926. Both in our set of denominations, and nationwide, the number of churches declined; the number of members rose nationally but not for our denominations. This difference in membership trends is largely due to an acknowledged undercounting of Southern Baptist Churches by the 1936 census; the religious census itself cites as the correct number the yearbook figure that we use, which is 11,000 churches and 1.8 million members higher. Correcting the 1936 census data changes the ratios to $24 \%$ of churches and $18 \%$ of members, which are closer to the 1926 figures. These corrected church and membership data are shown in the last two columns of Panel A.

Panel B of Table 2 shows a comparison of financial data for our denominations relative to the full set of denominations on a per church basis. Overall expenditures per church are very similar in both 1926 and 1936; the denominations we use spend slightly more per church than the full set. The division into operating expenditures and benevolences is somewhat different, however. In our set of denominations, benevolences amounted to $22 \%$ of total expenditures in 1926 (\$844/\$3890), compared to only $18 \%$ nationwide. Benevolences also fell faster in our set of denominations than overall over this period, declining by 32\% in our set (from $\$ 844$ to $\$ 576$ ) but only 23\% nationally.

This discrepancy may arise from nonrandom attrition between the 1926 and 1936 samples. For example, the two main Methodist denominations, the Methodist Episcopal Church and the Methodist Episcopal Church, South, had 29.8\% and 36.7\% fewer churches reporting in 1936 than in 1926, respectively. These were two of the largest denominations in the country and both had below average levels of per-member relief spending compared to other churches. Their low response rate in 1936 may thus lessen the apparent decrease in spending observed for all churches that year. 
The rightmost column in panel B addresses this issue by excluding these Methodist churches from both years. With this change, benevolence spending for all denominations declines by $29 \%$ between 1936 and 1926 — a decline very close to the 32\% figure for our subsample of denominations.

The 1936 census also collected more detail on church expenditures that can allow us to explore in more detail our measure of benevolences. In panel C of Table 2, we divide our total measure of benevolent spending into three components: Home Missions and Local Relief, Foreign Missions and spending sent to denominational “Headquarters,” and other benevolent spending.

While the first category clearly represents local charitable activities, we do not have good information about the charitable content of the remaining categories. It is very likely that in some cases important local relief spending does in fact fall into the "spending to Headquarters" category. For example, if a local orphanage is financed primarily by denomination-level support, the funding would come from spending to the denominations headquarters. Furthermore, some churches (such as in the CCC) can credit local charitable spending towards their apportioned spending to headquarters, and it is unclear how such spending would be categorized here. We also have little information on "other expenditures”. As panel C of Table 2 shows, the share of spending on Home Missions and Local Relief is quite similar in our set of denominations to the national totals. Our denominations do have more spending on Foreign Missions and spending to Headquarters, and less on other categories.

Thus, our measure of benevolences may capture activities beyond local charity, which are not responsive to local government relief spending. To the extent that our variable is noisy because of additional spending, and to the extent that there is substitution within different spending categories in response to the New Deal, our results may be biased towards zero. ${ }^{3}$ Given this broad measure of benevolence, we are likely estimating a lower bound for crowd-out.

\footnotetext{
${ }^{3}$ A similar bias could arise if charitable church activity involved in-kind provision of services and volunteering that is not captured by our spending data.
} 


\section{New Deal Transfers}

Our other major data element for our analysis is information on relief spending under the New Deal. These spending data cover nearly all of the public relief spending undertaken during the great depression: General Relief spending (including spending undertaken by Federal Emergency Relief Administration, FERA), Work Relief spending (including spending undertaken by the Works Progress Administration, WPA, and the Civil Works Administration, CWA), Aid to Dependent Children, Aid to the Blind, Old Age Assistance, and local poor relief spending. Spending data include both federal spending and matching state spending under these programs.

The spending data are available for each state and each year, from 1933 to 1939. Prior to 1933, relief spending data are not available and are set to zero. This should not be a large problem given that public relief spending was relatively small before the New Deal. The exclusion of pre-New-Deal public spending may lead to an overestimate of the rise in government spending precipitated by the New Deal, if federal spending crowded out state spending, which in turn will lead to underestimates of how each additional dollar of New Deal spending affected church activity. Appendix B provides more information on the sources of these spending data.

\section{Means}

Table 3 shows the summary statistics for our data set. Means are weighted by church members; monetary figures are in 1929 dollars. Charitable church spending-essentially all spending by churches exclusive of operating expenditures—averages $\$ 2.63$ per member. Per capita relief spending is $\$ 10.76$, but this figure is artificially low given that relief spending is set to zero before 1933 (as discussed above). The average of per-capita public-relief spending from 1933 onwards is $\$ 16.44$ (the mean of per member charitable church spending over the same period is \$2.30). Total New Deal relief spending was about $\$ 14$ billion, or about $\$ 2$ billion a year. This figure is comparable to those in other studies (e.g., Wallis, Fishback, and Kantor, 2005). 
The mean of per-member charitable spending may seem somewhat small, but it should be noted that per-capita personal income at the time was only $\$ 520$. If one extrapolated our spending figures to other denominations, in most years charitable church spending would be a little under $10 \%$ of New Deal relief spending, a sizeable fraction.

The remaining variables include demographic characteristics such as the percent of the state population black, the percent of 7-13 year-olds attending school, the percent of women widowed, the number of farms per capita, the percent foreign born, the percent under age 18, the percent over 65, the population density, and the log of the state's population. The population data come annually from the BEA, the other demographic variables are taken from the decennial census and linearly interpolated. We attempt to control for the economic conditions of a state using per-capita personal income, and an employment index developed by Wallis (1989). This index measures employment levels for each state and each year, with 1929 benchmarked to 100 for all states. We also control for the percent of a state's voters voting democratic in the previous presidential election; this variable and political indices based on it have been included in many other studies of the New Deal (e.g., Wright, 1974, Couch and Shughart, 1998, Wallis, 1998). We also include the tenure of a state's representatives who are on the House Appropriations Committee. We will discuss this last variable more below.

\section{Section III: Empirical Strategy}

\section{Regression Framework}

Our analysis begins by estimating regressions of the form:

$$
\text { CHSPEND }_{\mathrm{dst}}=\alpha+\beta \text { GOVSPEND }_{\mathrm{st}}+\delta \mathrm{X}_{\mathrm{dst}}+\gamma \mathrm{Z}_{\mathrm{st}}+\eta_{\mathrm{dt}}+\lambda_{\mathrm{ds}}+\mu_{\mathrm{ry}}+\epsilon_{\mathrm{dst}}
$$

where CHSPEND is the level of per-member benevolent spending in denomination $\mathrm{d}$, in state $\mathrm{s}$, in year $\mathrm{t}$; GOVSPEND is the level government relief spending in state $\mathrm{s}$ in year $\mathrm{t}$; $\mathrm{X}$ is a set of controls for other denomination/state/year characteristics; $\mathrm{Z}$ is a set of controls for other state/year characteristics; $\lambda_{\mathrm{ds}}$ is a set of fixed effects for each denomination in each state; $\eta_{\mathrm{dt}}$ is a set of fixed effects for each denomination 
in each year; and $\mu_{\text {ry }}$ are fixed effects for each of the nine census regions of the country in each year. If there is crowd out of church spending by government spending, then $\beta<0$.

Church benevolent spending is expressed in per-member terms because of the incomplete coverage of our sample. In some states, we have a large share of all church-goers; in other states, we only have a smaller share. For example, in Utah the members in our 6 denominations make up barely $1 \%$ of the population, whereas in North Carolina the members in our 6 denominations make up 17\% of the population. By normalizing by members, we allow a comparable measure across our units of observation. If these denominations are representative of other denominations in terms of the crowd-out effects of government spending, then our giving per member results can be extrapolated to compute an aggregate crowd-out estimate. Government transfer spending is expressed in per capita terms since we assume that church benevolence is responding to the generosity of government transfers per citizen.

We also control for characteristics varying at the denomination/state/year level, such as the number of churches and church members (both logged). Controls at the state/year level include the aforementioned controls for age, race, education, and economic conditions shown in Table 3.

Our model includes fixed effects for each denomination*state cell. This allows us to control for any secular differences in giving across areas, across denominations, and even across areas within a denomination. Indeed, different units of analysis even within a denomination may have very different tastes for benevolent activity. For example, within the PCUSA denomination in 1931, the level of benevolent activity per member varied from a low of $\$ 0.44$ in South Carolina to a high of $\$ 9.77$ in Kentucky. Our denomination*state controls will capture this heterogeneity, to the extent that it is fixed over our sample period.

In addition, there may be important denomination-specific trends in charitable activity. We therefore also include a full set of denomination*year interactions in the model as well.

A more fundamental concern is the possibility of an important unobserved determinant of both government spending and church benevolence-economic conditions in the state. States that are hit harder by the great depression would naturally be expected to receive more government transfers. At the 
same time, economic conditions have two potential effects on church benevolence. On the one hand, a recession would lead to more demand for church benevolence, which could raise church spending levels, leading to a positive correlation between government spending and church spending. On the other hand, a recession would lower personal incomes and therefore church charitable contributions, lowering the potential supply of church benevolence, leading to a negative correlation between government spending and church spending. In either case, unobserved differences in economic performance across states could lead to bias in the crowd-out estimates.

A suggestion that this correlation is not driving our results can be found in the time series graph in Figure 1. The Great Depression began in 1929, while New Deal spending did not begin until 1933. Thus, if economic factors, and not government spending, were driving downward church benevolent activity, it should become apparent in the years between 1929 and 1933. Yet, as is clear from Figure 1, the amount of resources church members devoted to relief was fairly flat until 1933. There is a very sharp decline in 1933, however, which coincides exactly with the start of the New Deal. (The slight spike in New Deal spending in 1934 is driven by the brief but massive Civil Works Program, which was in operation during the winter of that year). The picture therefore argues for a more complex story than one where economic conditions led to a spurious decline in church activity during this time period.

Nevertheless, we include the available controls for economic conditions discussed above in our models to capture the differential effects of the depression across the states. We also undertake three additional steps to address this concern:

\section{Region*Year Interactions}

First, we include in our regression a full set of region*year interactions, where regions are the nine different areas of the country defined by the Census Bureau. Thus, to the extent that economic shocks are region-wide, we control for them, and only identify our model using variation in government spending over time by state within a region. 


\section{Instrumental Variables Strategy}

We also pursue an instrumental variables strategy to account for the endogeneity of government spending. We follow Couch and Shughart (1998), Anderson and Tollison, (1991), Fishback, Haines, Kantor, (2002), and Wallis (1998) in using the power of the state's congressional delegation as an instrument for the distribution of New Deal spending. Couch and Shughart (1998) point out that in the 1930s an Office of Management and Budget had not yet been established in the executive branch, and congress therefore played an even larger role in influencing expenditures than is the case today. Anderson and Tollison (1991) argue that spending was strongly influenced by Appropriations Committees, which crafted bills before they were submitted to Congress. We therefore use as our instrument the tenure of a state's congressional representatives who were on the Appropriations Committee. (As in previous research, if a state did not have an individual on the committee, its tenure is set to zero). The instrument is measured in months, from the time a representative took office through the present. ${ }^{4}$ The data used to make the instrument were made available by John Wallis and were supplemented by the Official Congressional Directory. ${ }^{5}$

Of course, if congress influenced total New Deal spending in the same manner that it influenced New Deal relief spending, then we will understate the financial flows into states, and may therefore overstate crowd-out effects if church spending responded to other aspects of the New Deal. Relief spending was the majority (more than 60\%) of total New Deal spending, but there was other spending through agencies such as the Public Works Administration, which constructed dams, airports, hospitals, and other public works. Yet Couch and Shuggart (1998) show that this same channel does not appear to

\footnotetext{
${ }^{4}$ It is possible that it is not absolute tenure on the committee that should determine power, but rather the relative tenure of individuals on the committee. The results below are robust to using an instrument that simply ranks committee members based on their tenure.

${ }^{5}$ Previous research has considered a number of other measures of congressional influence. Our results are robust to including other measure of congressional influence, such as those used by Wallis (1998) and Anderson and Tollison (1991). However, most other measures are weak in the first stage, or are significant and correctly signed but driven by very little variation. For example, Anderson and Tollison include measures of leadership in the House and Senate, and like them we find a positive and significant effect on spending of a state having a senator who is majority leader or president pro tem. However, given controls for state fixed effects, this result is driven entirely by a change in the Senate majority leadership position from Arkansas' Joseph Robinson to Kentucky's Alben Barkley in 1937. We therefore focus on the more robust variation available with the Appropriations Committee instrument.
} 
have operated for other aspects of New Deal spending, beyond relief spending through projects such as the CWA and WPA. ${ }^{6}$

One reason that relief spending may have been particularly sensitive to political considerations is that the FERA, the CWA, and the WPA were all directed by Harry Hopkins. Hopkins had a large degree of influence on the administration of funds in these programs (Wallis, Fishback, and Kantor, 2005). With regard to the WPA, the largest of these programs, Hopkins had discretion in allocating funds and the criteria he employed to distribute the funds were clandestine. The New York Times of December 29, 1938, wrote, “The allocation of WPA funds cannot indefinitely be permitted to rest upon the personal discretion of any one man or small group of men. The relief funds belong to the whole country. Their allotment must be placed upon a basis that the whole country understands clearly and accepts as fair” (New York Times, 1938). When called before a special congressional committee to discuss the geographical distribution of work created by the WPA, he stated, "A lot of this is nothing but a matter of opinion. If somebody else were administering this and dividing up these 2,600,000 [jobs] among 48 states he might do it differently” (US Senate, 1938, p.1396).

Charles (1963) writes, “Hopkins devoted considerable attention to his relations with Congress,” and that "congressmen who supported the work relief program” got "special attention." This is not surprising given that relief programs such as the FERA and WPA depended on annual appropriations and congressional reauthorization. Couch and Shuggart provide evidence that states whose congressional representatives supported the initial legislation creating the WPA received more funds, all else equal. In essence, the Appropriations Committee controlled the size of the New Deal "pie”, and Hopkins controlled its distribution. Past evidence suggests that Hopkins used his control over distribution to "buy" increases in the overall level of New Deal relief spending.

Of course, many of the same factors that are associated with the impact of the recession on a state may be associated with the tenure of its representatives on the Appropriations Committee. But recall that our model includes state fixed effects, so that we are identified off changes in the tenure. For example, at

\footnotetext{
${ }^{6}$ See tables 8.9 and 8.14 in Couch and Shughart (1998) for regressions on these other types of spending.
} 
the start of 1937 the Appropriations Committee was headed by James P. Buchanan of Texas. Buchanan exercised considerable influence over spending decisions and President Roosevelt regularly consulted with him before bills were considered by the committee (Patenaude, 1983). Buchanan also used his role on the committee to influence the administration of New Deal programs in an effort to benefit his constituents. For example, the nation’s first Social Security District Office was opened in Buchanan’s hometown after he threatened the social security board with a $25 \%$ reduction to the Board's proposed budget (Dewitt, 2001).

However, in 1937 Buchanan died unexpectedly of a heart attack, leaving Texas with much less influence on the committee. ${ }^{7}$ Incidentally, total New Deal relief spending in Texas (in constant dollars) fell by $15 \%$ the following year; a decline much larger than the average for other states (2.5\%). At the same time, non-relief spending under the New Deal fell in Texas by an amount comparable to other states.

Of course, non-mortality related changes in tenure are potentially endogenous to economic conditions that drive church charitable activity. However, since New Deal spending did not begin until 1933, but our data start in 1929, we can further insulate ourselves from causality concerns by using as the excluded instrument not the appropriations tenure itself, but the interaction of tenure with a dummy for years 1933 and later. This allows us to actually include the appropriation tenure itself as a regressor, controlling for general unobserved correlation between changes in tenure and changes in church charitable activity, and to identify our model only from changes in the relation between appropriation tenure and charitable activity after 1933, relative to before. Thus, the only way that omitted factors could bias this comparison would be if they were associated with changes in a state representative's tenure on the appropriations committee, and if they operated only after 1933 and not before.

\footnotetext{
${ }^{7}$ Interestingly, both the chairman before and chairman after Buchanan also died in office.
} 


\section{Alternative Instrument}

Our final strategy for dealing with concerns over omitted determinants of government spending and church charitable giving is to consider the robustness of our findings to an alternative instrumental variables strategy: using the differential impact of the New Deal on states which faced different fiscal constraints when responding with their own matching spending. A number of New Deal programs provided matching grants to states to increase relief spending, so the impact of these programs was proportional to the extent to which states could raise those matching funds. Some states had a much more difficult time raising the matching funds than did other very comparable states, due to constitutional restrictions on the amount of debt that the state could incur. In these constitutionally restricted states, in fact, spending grew the most slowly when the New Deal was enacted. We therefore assess if church charitable activity rose relatively in those states where government spending grew less due to debt restrictions.

\section{Section IV: Results}

\section{Basic Results}

Table 4 shows our main results. The standard errors in all regressions account for heteroskedasticity and are corrected for clustering at the state level, following the suggestion of Bertrand et al. (2004). All regressions include controls for denomination-by-year dummies, denomination-by-state dummies, and census region-by-year dummies. Results are weighted by church membership. ${ }^{8}$ The unit of observation is a given denomination in a particular state each year from 1929 to 1939.

Column (1) presents the OLS estimate of the impact of government relief spending on church charitable spending. The coefficient on government spending is negative, suggesting crowd out, and statistically significant. The coefficient indicates that, for every dollar of government spending per capita, church spending per member fell by 2.3 cents. Over our sample period, roughly $50 \%$ of the population

\footnotetext{
${ }^{8}$ The estimate of crowd-out in an unweighted regression is close to the results reported here.
} 
were church members. ${ }^{9}$ Thus, if this coefficient can be extrapolated to denominations not covered by our sample, the result indicates that each dollar of government spending crowded out 1.15 cents of church benevolence.

Table 4 reports the coefficients on the other explanatory variables included in the regression as well. There is no direct effect of (the non-interacted) house appropriations tenure variable. There is a negative effect on charitable activity of having more Democrats in the state and of having more blacks. There is a positive effect on the percent of children in school and the number of widowed females, perhaps reflecting sources of demand for charitable care. None of the remaining controls is significant.

As discussed earlier, there are a number of reasons to be suspicious of this OLS result. We therefore turn to the instrumental variables strategy discussed earlier. The second column of Table 4 shows the first stage. There is a very strong positive correlation between our instrument, the interaction of house appropriations committee tenure, and New Deal spending: each month of tenure leads to 1.2 cents more New Deal spending per capita. This is a reasonable estimate: averaging across all states and years, the typical state had a tenure on the appropriations committee of roughly 120 months, suggesting a mean effect of $\$ 1.50$ per capita of New Deal spending due to appropriations committee tenure. That is, we estimate that about $10 \%$ of New Deal relief spending was allocated across states based on political considerations.

The third column shows the 2SLS estimates of our model. Instrumenting by appropriations tenure, interacted with a dummy for 1933 or later, yields a significant coefficient showing that each dollar of government spending per capita leads to 5.7 cents less church spending per member. Using the extrapolation approach from earlier, this finding suggests that each dollar of government spending lowered church benevolence by about 2.9 cents.

\footnotetext{
${ }^{9}$ The 1926 Census of religion, which has the most reliable estimates of church membership, reports that membership was equal to $47 \%$ of the population in that year.
} 


\section{Interpretation}

The 2SLS estimate in Table 3 clearly indicates a significant crowd out of church benevolence by government spending. Yet the coefficient is small, with an estimated reduction in church benevolence of 2.9 cents per dollar of government spending. While small in absolute terms, this finding is fairly large relative to the size of church benevolence. From 1929 to 1932, the last year before the New Deal, annual church benevolent spending in the U.S. averaged about $\$ 180$ million. This is a little less than $10 \%$ as large as the average annual New Deal transfer spending over the 1933-1939 period of $\$ 2$ billion. All else equal, the largest possible degree of crowd out of church benevolence by the New Deal would have been ten cents per dollar of spending. Relative to this benchmark, then, crowd out is fairly large, roughly $30 \%$ of the total amount possible.

Another way to make this point is to examine the decline in charitable church activity after the New Deal. Per-member charitable church spending fell from \$3.27 between 1929 and 1932 to \$2.30 between 1933 and 1939. If one calculates fitted values based on the main regression (column 3 of Table 4) while constraining government spending to be zero, predicted charitable church spending from 1933 to 1939 is $\$ 3.24$ per member. The data suggest that the New Deal can explain essentially the entire decline in church activity during the period 1933 to 1939. This conclusion is consistent with Figure 1: church charitable spending remained relatively strong during the worst part of the great depression (1929-1932), but not after the government raised relief spending starting in 1933.

In monetary terms, if the typical church had spent about a dollar more per member on relief over this time period (as would have been the case with no New Deal), then without the New Deal church activity would have been \$385 million higher (in 1929 dollars) over this time period—about \$4 billion in year 2000 dollars. The New Deal crowded out a substantial amount of charitable church activity.

Yet another way to see this point is to use a different framework, estimating a log-log model of church benevolence on New Deal transfer spending. Since the latter was zero until 1933, we can only estimate this model from 1933-1939. Thus, we use a more restrictive version of the instrument which is

just appropriations tenure itself. We show the first stage from such a model in column (4) of Table 4, and 
the 2SLS estimates in column (5). The instrument is highly significant, while the 2SLS estimate is significant at about the $8 \%$ level. The estimated coefficient on the log of government spending per capita is -0.77 . Given that church spending was a little less than $10 \%$ of public relief spending over this time, an elasticity of 0.77 suggests that at the mean crowd out was about seven cents on the dollar.

\section{Section V: Sensitivity Checks}

In this section, we consider a variety of alternative specifications designed to assess the robustness of our central crowd-out finding. In each case, we show the coefficient of interest from full regression specifications such as those shown above.

\section{Sensitivity to Denomination}

One concern about the findings may be that they are driven by one particular denomination. While the relatively small sample sizes of each denomination make repeating the standard regression on a case-by-case basis problematic, we can address this concern by repeating the standard regression dropping one denomination at a time. Table 5 shows the results of this exercise. The estimates are strikingly robust to variations in the set of denominations. The coefficient in all cases is close to the spending coefficient in column 3 of Table 4. In four of the six cases the coefficient remains at least marginally significant, and it always remains at least 1.33 times as large as its standard error. Our results are not driven by only one denomination.

\section{Operating Expenses}

Some of the alternative hypotheses for our findings also have implications for other church expenditures. For example, if our results are driven by the fact that donations to churches fall as the economy sours, then churches should not only reduce benevolent activity, but also other spending as well (unless the incidence of lower donations is $100 \%$ on church benevolence). We can therefore test for this alternative by replacing our dependent variable with church operating expenditures per member, rather 
than church benevolence per member. An additional virtue of this regression is that it can speak to the question of whether churches shifted spending from benevolences to other categories, or whether overall spending fell.

As the first column of Table 6 shows, there is a positive effect of New Deal spending on operating expenditures. This is inconsistent with the alternative hypothesis for our finding, and consistent with church shifting of spending to operating expenditures. The coefficient is very imprecisely estimated, however, so that we cannot draw any strong inferences from the finding.

\section{Religious Census Data}

As noted earlier, there are data available for 1926 and 1936 on benevolent activity from the Religious Census. The advantages of this data set include the fact that the data cover all states and virtually all denominations in the country. The disadvantages of the data set include the facts that it cannot be broken down by denominations across states (and thus the sample sizes are small); that it only includes two years; that participation in the census was lower in 1936, with potentially non-random attrition between the two years; and that our economic controls are not available for 1926, so we cannot include them in the model.

The next two columns of Table 6 use these religious census data rather than our church yearbook data. The second column of Table 6 shows our basic 2SLS estimates using the religious census. The coefficient is -0.038 , which is about two-thirds as large as the coefficient using the higher quality data from our six denominations. But the coefficient is not statistically significant. In the next column, we replicate our previous analysis, but exclude the region*year interactions, which use up much of the variation in this limited data set (with only two years of data). In this case, the coefficient increases slightly in absolute value and becomes statistically significant. Thus, these data confirm the significant crowd out of government spending, albeit at a somewhat lower level.

\section{Alternative Instrumental Variables Strategy: State Debt Limitations}


Our key identifying assumption for this analysis, as discussed earlier, is that changes in appropriations committee tenure, after 1933 relative to before, are exogenous with respect to church charitable activity. To confirm our findings, we pursue another instrumental variables strategy as well, using variation across states in the ease with which they could use debt to finance the state matching spending required to take advantage of the New Deal.

During the great depression, a number of states faced restrictions on using debt to finance relief spending or government spending in general. These restrictions usually took one of two forms: state law required a constitutional amendment to authorize debt financing (in 23 states) or required referendum approval (15 states). ${ }^{10}$

These restrictions likely impacted a state’s ability finance relief spending (Shawe, 1936). As Wallis (1984) points out, "all of the relief programs, except the CCC, were jointly financed by federal, state, and local governments. Each program required explicit or implicit matching of federal funds for state and local contributions.” Wallis (1984) shows that for relief spending, increases in state expenditures lead to increases in federal grants (see also Couch and Shughart, 1998, page 203). The federal government itself noted that, "the terms on which Federal aid is available are not such as to foster a distribution of funds in full accordance with need and capacity,” and in particular given the importance of state matching, "the less money a State can afford to raise, the less Federal aid will it receive” (National Resource Planning Board, 1942, page 475).

Of course, states had an incentive to try to get around these fiscal restrictions. For example, Shawe (1936) writes, “A favorite method of overcoming constitutional limitations on borrowing powers is the creation by State legislatures of special tax "districts" or "corporations" for the purpose of public improvements, etc.” Shaw provides a list of states exploiting such loopholes; we will consider these loopholes in the analysis.

Figure 2 shows the variation in state debt limits across the country. The darkest areas have the fewest restrictions. The black states require only approval by the state legislature to incur debt. The dark-

${ }^{10}$ Data on states facing restrictions come from table G-2 of Shawe (1936). 
gray areas are areas where states exploit the corporation and division loopholes mentioned above. These two types of states will be considered free of fiscal constraints in the regressions. Among the other states, the light gray states are those requiring referendums to incur debt and the white states are those requiring a constitutional amendment. These last two groups will be the ones considered facing fiscal constraints in the regressions; they make up 30 out of 48 states and about $2 / 3^{\text {rds }}$ of the observations.

Once again, our model includes state fixed effects, so we are not simply comparing states with and without these debt limits. Rather, we use as instruments an interaction of the dummy for restrictive debt rules with a dummy for the year being 1933 or later, which is when the matching implications of these restrictions became relevant. Thus, this strategy compares the changes in church benevolent spending around the start of the New Deal in states poised to take advantage of the matching grants provided by the federal spending versus those who were less able to do so.

These two sets of states are very similar along observable dimensions before the New Deal, as shown in Table 7, which tabulates mean characteristics of the two sets of states from 1929 to 1933 . The two sets of states appear almost identical in economic terms, with very similar per capita income, farms per capita, and employment index scores. They are also similar along most demographic dimensions, such as percent of the population that are children, percent of the population that is elderly, percent of 713 year olds enrolled in school, percent of females widowed, and percent of the state voting Democrat in the previous election. The only sizeable difference between the states is in population density, which is higher in states without a debt limit. Fortunately, however, differences in population density do not appear to be associated with charitable giving in our earlier models, so it seems likely that this is not an important source of heterogeneity across the groups of states.

The fourth column of Table 6 shows the first stage regression for this instrument, using the denomination-level data set. ${ }^{11}$ There is a significant and sizeable negative impact of having constraining debt limits on New Deal spending at the state level, with states with such limits spending \$2.58 less per

\footnotetext{
${ }^{11}$ Using this instrument with the Religious Census data set yields coefficients very similar to the original ones, although the results are somewhat imprecise.
} 
capita. ${ }^{12}$ The next column shows the results of our 2SLS equation using this alternative instrument. The results here are also negative and significant, and larger in absolute value than the results using our other instrument: they suggest that each dollar of New Deal spending per capita leads to 12.4 cents less benevolence per member, for an implied crowd-out estimate of 6.2 cents per dollar of government spending.

Column 6 of Table 6 combines these two instruments, and produces a crowd-out estimate of 8.4 cents reduced benevolence per member, or 4.1 cents per dollar of government spending. As noted below Table 6, this specification easily passes a test of overidentifying restrictions (as should have been clear from the similarity of the coefficients in the previous two columns). Thus, an alternative identification strategy suggests even larger crowd out than does our use of appropriations committee tenure. ${ }^{13}$

\section{Part VI: Conclusions}

Religious bodies in the U.S. have been, and will continue to be, important providers of social services. Yet the role of religious organizations as providers of charitable activity shrank significantly during the 1930s, the period of government growth through the New Deal. In this paper, we assess the causal link between these trends. We do so by exploiting the fact that a major determinant of New Deal transfers was the political power of a state's congressional delegation, in particular the tenure of a state's politicians on the House Appropriations Committee. States that saw an increase in the tenure of their representatives on the Appropriations Committee, after 1932 relative to before, saw a large rise in New Deal spending. These same states saw a sizeable decline in the level of their charitable church spending. We confirm the robustness of this finding in a number of ways, including the consideration of a very

\footnotetext{
${ }^{12}$ As mentioned earlier, we do not have data on public relief spending prior to 1933. If one assumes that the level of relief spending, all things equal, was actually lower in constrained states before 1933, then our first stage coefficient overestimates the effect of the constraints. Our second stage coefficient will therefore be biased towards zero.

${ }^{13}$ The results from this instrument are more sensitive to the exclusion of particular denominations, however: the estimate is close to zero when the PCUSA denomination is excluded, while it is almost twice as large when the LCMS is excluded. Nevertheless, in five of the six cases of excluding particular denominations the coefficient remains significant and in all cases it is correctly signed.
} 
different instrument, showing that state debt limits led to a slower growth of New Deal spending and a more rapid growth of charitable church activity.

Our estimates confirm that government spending does crowd out private charity, at least through churches. Relative to the total level of New Deal spending, this crowd-out was quite small, amounting to only 3\% of total spending. Relative to total church benevolent spending, however, the crowd-out was large, amounting to $30 \%$ of church benevolent spending, and explaining essentially all of the one-third decline in church benevolent spending over the 1933-1939 period.

These results may have important implications for the optimal division of charitable activity between the government and the private sector. If churches are superior providers of social services, then the government is imposing a sizeable cost by providing those services itself. At the same time, crowd out is far less than full, and overall provision would be likely to fall significantly if the government retrenches. Unless church provision is many times more efficient than government provision, reductions in government provision will result in an overall reduction in charity in the U.S.

There are a number of questions left unaddressed by our analysis that could be useful subjects for future work. First, we are using a rough categorization of church benevolences, and it would be helpful to use more detailed data to investigate which components of church spending are responding to government spending, and whether there are substitutions across the components included in our measure (in which case our estimate is biased downwards). Second, our results differ substantially from those of Hungerman (forthcoming), who finds crowdout of $20-38 \%$. This may be due to the fact that he is examining a much smaller decrease in government spending. Further exploration is needed into church responsiveness to spending increases vs. decreases, and non-linearities in that responsiveness.

Finally, while churches remain an important source of social services, providing over \$24 billion in philanthropic services annually (Biddle, 1992), church charitable giving is only one element of private charity that might be crowded out by government intervention. Organizations in the "human services" subsector of the non-profit field (such as food banks and the Red Cross) had revenues exceeding \$54 billion in the year 2000 (Center on Philanthropy, 2004). If these organizations and other charitable 
providers respond in similar ways to changes in government spending, the total amount of crowd-out could be multiples of our finding. 


\section{References}

Abrams, Burton, Schmitz Mark. (1984). The “Crowding-Out” Effect of Governmental Transfers on Private Charitable Contributions: Cross-section Evidence. National Tax Journal 37, 709-738.

Anderson, Gary, and Tollison, Robert. (1991). Congressional Influence and Patterns of New Deal Spending. Journal of law \& Economics 34, 161-175.

Andreoni, J., 1993. An Experimental Test of the Public-Goods Crowding-Out Hypothesis. The American Economic Review 82, 1317-1327.

Baird, Enid, and Lynch, John (1942). Public and Private Aid in 116 Urban Areas. Government Printing Office: Washington.

Bergstrom, Ted, Blume, Larry, Varian, Hal, (1986). On the Private Provision of Public Goods. Journal of Public Economics 29, 25-49.

Bertrand, Marianne, Duflo, Esther, and Mullainathan, Sendhil (2004). How Much Should We Trust Differences-inDifferences Estimates? Quarterly Journal of Economics 119, 249-275.

Biddle, Jeff (1992). Religious Organizations. In: Charles T. Clotfelter (Ed.), Who Benefits from the Nonprofit Sector? University of Chicago Press: Chicago .

Bureau of the Census. (1927). Financial Statistic of States: 1926. Government Printing Office: Washington.

Bureau of the Census. (1928). Financial Statistic of Cities Having a Population of Over 30,000: 1926. Government Printing Office: Washington.

Bureau of the Census. (1930). Religious Bodies: 1926. Volume I: Summary and Detailed Tables. Government Printing Office: Washington.

Bureau of the Census. (1941). Religious Bodies: 1936. Volume I: Summary and Detailed Tables. Government Printing Office: Washington.

Charles, Searle F. (1963). Minister of Relief. Syracuse University Press: Syracuse, NY.

Center on Philanthropy, the (2004). Giving USA. AAFRC Trust for Philanthropy: New York.

Cnaan, Ram A., Boddie, Staphanie, Handy, Femida, Yancey, Gaynor, and Schneider, Richard (2002). The Invisible Caring Hand: American Congregations and the Provision of Welfare. New York University Press: New York.

Cnaan, Ram A., Winebrug, Robert, and Boddie, Staphanie. (1999). The Newer Deal. Columbia University Press: New York.

Couch, Jim F,. and Shughart, Willim F. II. (1998) The Political Economy of the New Deal. Edward Elgar: Cheltenham, UK.

DeWitt, Larry (2001). How the First Social Security Field Office Came to be in Austin Texas. Social Security Research Note \#10.

Dudley, Carl, and Roozen, David. (2001). Faith Communities Today. Hartford Institute for Religious Research.

Federal Works Agency (1940). WPA Statistical Bulletin. Washington, DC.

Fishback, Price, Haines, Michael, and Kantor, Shawn. (2002). The Welfare of Children During the Great Depression. NBER working paper 8902.

Gray, Joan, and Tucker, Joyce. (1986). Presbyterian Polity for Church Officers. Westminster/John Knox Press: Louisville, KY.

Hodgkinson, Virginia A., Weitzman, Murray S., and Kirsch, Aruthur D. (1988). From Belief to Commitment: The community Service Activities and Finances of Religious Congregations in the United States: Findings from a National Survey. Independent Sector: Washington.

Hungerman, Daniel M. (Forthcoming). Are Church and State Substitutes? Evidence from the 1996 Welfare Reform. Journal of Public Economics.

Katz, Micheal B. (1996). In the Shadow of the Poorhouse. Basic Books: New York.

Khanna, Jyoti, Posnett, John, and Sandler, Todd. (1995). Charity Donations in the UK: New Evidence Based on Panel Data. Journal of Public Economics, vol. 56, pp. 257-272.

Khanna, Jyoti, Sandler, Todd, (2000). Partners in Giving: The Crowding-In Effects of UK Government Grants. European Economic Review 44, 1543-1556.

Kingma, Bruce. (1989). An Accurate Measurement of the Crowd-Out Effect, Income Effect, and Price Effect for Charitable Contributions. Journal of Political Economy 93, 1197-1207.

Johnson, Ernest F. (1930). The Social Work of the Churches : a Handbook of Information. New York City: Department of Research and Education of the Federal Council of the Churches of Christ in America.

Lindsey, Lawrence, and Steinberg, Richard (1990). Joint Crowdout: An Empirical Study of the Impact of Federal Grants on State Government Expenditures and Charitable Donations. NBER working paper 3226. 
National Resources Planning Board (1942). Security, Work, and Relief Policies. US Government Printing Office: Washington.

New York Times, The (1938). The Reform of Relief. Editorial, December 29, page 18.

Okten, C., Weisbrod, B., 2000. Determinants of Donations in Private Nonprofit Markets. Journal of Public Economics 75, 255-272.

Olasky, Marvin. (1992). The Tragedy of American Compassion. Regnery Gateway: Washington.

Patenaude, Lionel V. (1983). Texans, Politics, and the New Deal. Garland Publishing: New York.

Payne, Abigail A. (1998). Does the Government Crowd-out Private Donations? New Evidence from a Sample of Non-profit Firms. Journal of Public Economics 69, 323-345.

Reece, William S. (1979). Charitable Contributions: New Evidence on Household Behavior. American Economic Review 69, 142-151.

Roberts, Russell D. (1984). A Positive Model of Private Charity and Public Transfers. The Jounral of Political Economy 92, 136-148.

Shawe, Earle K. (1936). An Analysis of the Legal Limitations on the Borrowing Power of the State Governments. Monthly Report of the FERA (June), 121-133.

Steinberg, Richard. (1991). Does Government Spending Crowd-out Donations? Interpreting the Evidence. Annals of Public and Cooperative Economics 62, 591-617.

Straub, John D. (2004) Fundraising and Crowd-out of Charitable Contributions: New Evidence from Contributions to Public Radio. Working paper.

U.S. Senate. (1938). Special Committee to Investigate Unemployment and Relief ("Byrnes Committee”). Unemployment and Relief: Hearings Before a Special Committee to Investigate Unemployment and Relief. US Government Printing Office: Washington.

Wallis, John Joseph (1998). The Political Economy of New Deal Spending Revisited, Again: With and without Nevada. Explorations in Economic History 35, 140-170.

Wallis, John Joseph (1989). Employment in the Great Depression: New Data and Hypotheses. Explorations in Economic History 26, 45-72.

Wallis, John Joseph (1984). The Birth of Old Federalism: Financing the New Deal, 1932-1940. The Journal of Economic History 44, 139-159.

Wallis, John Joseph, Fishback, Price, and Kantor, Shawn. (2005). Politics, Relief, and Reform: The Transformation of America's Social Welfare System During the New Deal. NBER working paper 11080.

Winslow, Emma (1937). Trends of Different Types of Public and Private Relief in Urban Areas, 1929-35. Government Printing Office: Washington.

Works Progress Administration (1939). Analysis of the Civil Works Program. June 10. Washington, D.C.

Works Projects Administration (1942). Final Statistical Report of the Federal Emergency Relief Administration. US Government Printing Office: Washington.

Wright, Gavin. (1974). The Political Economy of New Deal Spending: An Econometric Analysis. The Review of Economics and Statistics, 56, 30-38.

Wuthnow, Robert (2004). Saving America? Faith-Based Services and the Future of Civil Society. Princeton University Press: Princeton, NJ. 


\section{Appendix A: Data on Church Activities}

Each denomination's data were copied from a denominational yearbook into excel files by a group of research assistants. (The data were then checked for errors by a second group of research assistants). Information from this appendix was taken from the yearbooks themselves and in some cases from discussions with members of the denomination. Especially helpful discussants are mentioned below. The appendix was created with the help of Ariel Edelstein and Matt Levy.

Table A3 lists which denominations are located in which states.

\section{Congregational and Christian Churches}

The data were taken from the Year Book of the Congregational Christian Churches of the United States of America. Most data come from "Summary Table 1: Comparative Table by States." Data on the number of churches reporting benevolences and post-1937 data on the location of the churches in a district were taken from the church-level tables in the yearbook.

Benevolent spending data for this denomination come from two categories: apportioned expenditures and benevolent expenditures. We use the Total Membership category for membership. See Table A1 for definitions of benevolence for this denomination and Table A2 for definitions of membership.

The CCC merged with the General Convention of the Christian Church (of Seattle, Washington) on June 27, 1931. Data for the years prior to 1931 do not include the several hundred churches of the GCCC. (The data include information on nearly 6,000 churches prior to the merger). (The CCC merged with the Evangelical and Reformed Church into the United Church of Christ in 1957.)

The CCC uses the calendar year as its fiscal year for the entire series. Apportionments received by the national Boards until January 10 are counted as having been made the previous year.

Prior to 1938, data in the yearbook were aggregated to the state level. From 1938 onwards, however, the data were aggregated by regional church bodies, these bodies are (confusingly) referred to in the yearbook as "states" but the area they cover does not always perfectly match up with actual states. For all of the years after 1938, the RAs collected information on the geographic location of each church in a given regional body (they got this information by looking at church-level tables available in the yearbook). We use this information to estimate the geographic area covered by the churches in each regional body after 1938. If a regional body is multi state, we put it in the state that houses at least $80 \%$ of its churches; if there is no state with $80 \%$ of the regional body's churches the body is not included.

Thanks the Reverend Doctor Harold F. Worthley, Executive Secretary and Archivist of the Congregational Christian Historical Society.

\section{Lutheran Church-Missouri Synod}

The data were taken from the Statistical Yearbook of the Lutheran Church-Missouri Synod. Most data come from the "Summarized Total of Parochial Reports" tables.

Benevolent spending data come from the Contributions for Work at Large variable, operating expenditures come from the Contributions for Work at Home variable, and membership data come from the Baptized Members variable. (From 1938 on, Contributions for Work at Home was called Contributions for Home Purposes and Contributions for Work at Large was called Contributions for Outside Purposes). Definitions of the benevolent spending and membership data are given in Tables A1 and A2.

The 1932 yearbook printed incorrect values for both Contributions for Work at Home and Contributions for Work at Large. The printed "change from previous year" category, however, appears to be correct. The values in the data set use the 1931 values incremented by the appropriate change.

Data in the yearbook are organized by district, and districts sometimes cross state lines. The yearbook provides the primary contract address for each pastor in a district; we collected this information for the years 1927, 1932, and 1937 and used it to estimate the geographic area covered by a given district (data on the location of churches in a district were not available). Information on the years not collected was filled in with linear interpolation. A district was considered to be located in a given state if at least $80 \%$ of its pastors resided in that state; districts that did not have at least $80 \%$ of all pastors living in any one state were excluded from the analysis.

Thanks to John O’Hara, Research Analyst at the Lutheran Church-Missouri Synod, and to the Reverend Marvin Huggins, the Associate Director for Archives \& Library at the Concordia Historical Institute. 


\section{Northern Baptist Convention}

The data were taken from the Year Book of the Northern Baptist Convention. Data were taken from the table "Summary of Denominational Statistics."

Benevolent spending data come from the Denominational Missions and Beneficence variables (prior to 1932, these categories are reported together as Beneficence). Operating expenses come from the Local Operating Expenses and Property Debts and Improvements variables (prior to 1932, these two categories are reported together as Current Expense). Membership comes from the Total Membership variable. Definitions of the benevolent spending and membership data are given in Tables A1 and A2. The yearbooks entries are organized by state.

Thanks to Moureen Morrisey at the Office of the American Baptist Information Systems and to Betty Layton, Archivist at the American Baptist Historical Society.

\section{Presbyterian Church in the United States}

The data were taken from the Minutes of the General Assembly of the Presbyterian Church in the United States. Data came from the table "Statistical Summary by Synods and Presbyteries."

Benevolent spending data are taken from the Congregaional Missions and Assembly’s Home Missions variables, operating expenses are taken from the Current Expenses and Building Expenses variables, and members are taken from the Whole Number of Communicants variable. Definitions of the benevolent spending and membership data are given in Tables A1 and A2.

The data are broken down by Presbyteries, regional governing bodies that are often smaller than a state but sometimes cross state lines. The yearbook provides the location for each church in a Presbytery; we collected this information for most years in the 1930s and used it to estimate the geographic area covered by a given Presbytery. Information on the years not collected was filled in with linear interpolation. A Presbytery was considered to be located in a given state if at least $80 \%$ of its churches were locaed in that state; Presbyteries that did not have at least $80 \%$ of all churches located in any one state were excluded from the analysis.

This denomination is also sometimes called the Southern Presbyterian Church.

Some helpful information about this denomination came from Gray and Tucker (1986).

\section{Presbyterian Church in the United States of America}

The data were taken from the Minutes of the General Assembly of the Presbyterian Church in the United States of America. Data come from the tables that provide summary data by synods and presbyteries.

Benevolent spending data are taken from the Total Benevolences variable (prior to 1931, this variable was broken into two categories: Miscellaneous Benevolences and Denominational Benevolences). Members data come from the Net Total Members variable (sometimes called Net Total Communicants). For this denomination data on donations are available but data on operating expenditures are not; operating expenses are calculated as the difference between donations and benevolent spending. Definitions of the benevolent spending and membership data are given in Tables A1 and A2.

The Orthodox Presbyterian Church split away from the PCUSA in 1936. This split was minor and has no discernable impact on the data.

As in the PCUS data set, the data are broken down by Presbyteries, regional governing bodies that are often smaller than a state but sometimes cross state lines. The yearbook provides the location for each church in a Presbytery; we collected this information for the years 1929 and 1939 and used it to estimate the geographic area covered by a given Presbytery. Information on the years not collected was filled in with linear interpolation. A Presbytery was considered to be located in a given state if at least $80 \%$ of its churches located in that state; Presbyteries that did not have at least $80 \%$ of all churches located in any one state were excluded from the analysis.

\section{Religious Census}

Data from the religious Census were taken from Bureau of the Census. (1930), Volume I, Tables 17 and 18 , and Bureau of the Census. (1941), volume 1, Table 17 and 18.

The variables used to construct benevolent spending differ between the two years because the census in 1936 asked more detailed questions. Benevolent spending in 1926 comes from the variable "Expenditures for Benevolences, Missiones, etc.” Benevolent spending in 1936 comes from the variables "Home Missions,” "Foreign Missions,” "Local relief and Charity,” “To General Headquarters,” and “All Other Purposes.” In 1926, operating

expense data come from variable "For Current Expenses and Improvement" in 1926, and from the variables "Pastors' Salaries," “All Other Salaries,” "Repairs and Improvements," "Payment on Church Debt, Excluding 
Interest," and "Other Current Expenses, Including Interest." In both years membership is taken from the variable "Number of Members: Total." Benevolent spending is described in Table A1. Membership is highly idiosyncratic among all the denominations in the census, and no definition is given for it in Table A2.

The census questionnaire asked churches to record expenditures in a number of different categories, including a category titled "for all other purposes." Churches were then asked to record "total spending." Churches sometimes recorded total spending greater that the sum of spending recorded in each of the categories. Such residual spending is not included in either the operating expenses or the benevolent expenses in our data.

The 1936 census suffered from a marked decline in cooperation from churches, and this decline does not appear to have been random across churches. This issue is discussed in the text.

\section{Southern Baptist Convention}

The data were taken from the Southern Baptist Handbook. The specific name of the table the data come from changes somewhat over time, but often has a title such as "Summary of Southern Baptist Associations."

Benevolent spending data are taken from the "Contributions of Churches: For all Missions Education \& Benevolences," variable. Operating expenses come from the "Contributions of Churches for Local Purposes" variable. Membership comes from the "Total Membership" variable.

The tables are at the level of the state convention; these conventions generally adhere to state lines. We believe the only potential multi-state convention in the data is the "Maryland-Delaware" convention. Data on the geographic distribution of churches in this convention is not available during this time period. However, it is available in more recent year, and in recent years between $80 \%$ and $90 \%$ of the churches in this convention are located in Maryland. We therefore assume this convention is located in Maryland.

No data are available for Arizona's convention in 1933 (the data were not published in the yearbook).

Thanks to the Southern Baptist Historical Library and Archives, and to Lifeway Christian Resources.

\section{Appendix B: Data on Relief Spending}

Relief spending consists of General Relief spending, Work Relief spending, Aid to Dependent Children, Aid to the Blind, Old Age Assistance, and local poor relief spending.

The data do not include relief spending on a number of specialized General Relief programs, including the Emergency Education Program, the College Student Aid Program, the Rural Rehabilitation Program, and the Transient Relief Program. However, these programs were relatively small in scope. The data also do not include expenditures on the Civilian Conservation Corps. program; to our knowledge data on expenditures for this program are not available. Finally, as mentioned in the text, data on relief expenditures prior to 1933 are not available and are set to zero.

Aid to the Blind data come from annual volumes of the Social Security Yearbook.

Aid to Dependent Children data come from annual volumes of the Social Security Yearbook.

Civil Works Program Data come from the Works Progress Administration (1939), Table 11.

General Relief Data come from the Works Projects Administration (1942), Tables III and XXIII.

Old Age Assistance data come from annual volumes of the Social Security Yearbook.

Poor relief data come from the Works Projects Administration (1942). From 1936 onwards, the publication combines local poor relief data with General Relief spending data. The publication provides aggregated data on poor relief prior to 1936 in Table XX and Table XXI. The first table gives total poor relief spending for all states combined, each month from 1933 through 1935. The second table provides, for each state, cumulative poor relief spending over the period 1933-1935. We use these two tables to estimate poor relief in each state and each year. Using Table XX to calculate the proportion of total 1933-1935 relief spending undertaken in a given year, we then assume that the proportion of total 1933-1935 relief spent by each state in a given year mirrors the proportion spent by the entire nation in that year.

Works Projects Administration data come from the Federal Works Agency (1940), Table IX. 
Table A1: Definitions of Charitable Church Activity

\begin{tabular}{|c|c|}
\hline Denomination & Definition \\
\hline Census of Religion Data set (Multi-faith) & $\begin{array}{l}\text { All expenditures other than (a) local operating expenditures, (b) capital expenditures, and } \\
\text { (c) debt payments. Examples would include amounts given to home missions and local } \\
\text { relief, spending on foreign missions, donations to denominational headquarters, and other } \\
\text { benevolent spending. }\end{array}$ \\
\hline Congregational and Christian Churches & $\begin{array}{l}\text { All apportioned and unapportioned expenditures on benevolence, including gifts to } \\
\text { congregational and non-congregational enterprises. These enterprises would often be } \\
\text { related to charity or church extension activities. Apportioned gifts could also be given to } \\
\text { "authorized specials," which were expenditures made by a local church outside of their } \\
\text { regular budgeted activities towards a mission or organization (often a Para-church } \\
\text { organization) approved by the local church district. }\end{array}$ \\
\hline Lutheran Church-Missouri Synod & $\begin{array}{l}\text { All expenditures other than expenditures spent entirely within the congregation. } \\
\text { Examples include expenditures on local ministry, local ecumenical agencies, } \\
\text { denominational bodies, and the regional judicatory (also known as the district office; the } \\
\text { district is the regional governing body of the LCMS). These expenditures include } \\
\text { benevolences, and/or payments on apportionment. }\end{array}$ \\
\hline Northern Baptist Convention & $\begin{array}{l}\text { All denominational missions, including gifts to national societies and boards, home and } \\
\text { foreign missions, the convention itself, the state convention, men's and women's } \\
\text { societies, schools and colleges, and other charitable or benevolent activities. }\end{array}$ \\
\hline Presbyterian Church in the USA & $\begin{array}{l}\text { All payments made to any benevolent cause by all churches and all church societies, such } \\
\text { as Youth and Women's Organizations. Includes apportioned expenditures made to } \\
\text { Presbytery, Synod, and General Assembly organizations as well as expenditures given to } \\
\text { ecumenical agencies. }\end{array}$ \\
\hline Presbyterian Church in the United States & $\begin{array}{l}\text { Congregational and presbytery missions. These are expenditures by congregations and } \\
\text { presbyteries to support church expansion (such as financial support for new churches) and } \\
\text { local charitable activity. Includes apportioned expenditures on Presbytery Missions. }\end{array}$ \\
\hline Southern Baptist Convention & $\begin{array}{l}\text { Total amount of money spent on mission expenditures, including monies given to } \\
\text { national and international causes, all monies given to denominational and state } \\
\text { convention organizations, and local church missions. These various missions would } \\
\text { likely include activities for church extension and charitable activities. (This } \\
\text { denomination does not use apportionment.) }\end{array}$ \\
\hline
\end{tabular}




\section{Table A2: Definitions of Membership}

\begin{tabular}{|l|l|}
\hline Denomination & Membership Definition \\
\hline Congregational and Christian Churches & $\begin{array}{l}\text { The total number of members for all churches in the State-membership generally often } \\
\text { involved assent to Kansas City Statement of Faith (similar to a confession of faith), or } \\
\text { possibly a letter of transfer for individuals transferring from another CCC church. } \\
\text { Membership is for adults, not children. }\end{array}$ \\
\hline Lutheran Church-Missouri Synod & $\begin{array}{l}\text { The number of members on role as Baptized. This is a broader measure of membership } \\
\text { than the “communicating members” category offered in the yearbook. Baptized members } \\
\text { need not have reached an age suitable for completion of the confirmation program } \\
\text { required for a member to become a communicant. }\end{array}$ \\
\hline Northern Baptist Convention & $\begin{array}{l}\text { The total number of members for all churches in the region. The definitions of } \\
\text { membership used by local Northern Baptist churches are idiosyncratic. }\end{array}$ \\
\hline Presbyterian Church in the USA & $\begin{array}{l}\text { The number of resident and nonresident members or communicants in each church. These } \\
\text { members generally had to make a profession of faith in Jesus Christ; this was usually } \\
\text { done during adolescence or adulthood. Thus, this membership category does not include } \\
\text { young children. }\end{array}$ \\
\hline Presbyterian Church in the United States & $\begin{array}{l}\text { Total number of communicants. Communicants generally had to make a profession of } \\
\text { faith in Jesus Christ, this was usually done during adolescence or adulthood. Thus, this } \\
\text { membership category does not include young children. }\end{array}$ \\
\hline Southern Baptist Convention & $\begin{array}{l}\text { This includes resident members and non-resident members. The primary rite to } \\
\text { membership is baptism; memberships may therefore include baptized children (although } \\
\text { the Baptists traditionally reject infant baptism). Other membership criteria, such as the } \\
\text { need to take a membership class, vary from church to church. }\end{array}$ \\
\hline
\end{tabular}




\section{Table A3: Geographic Location of Each Denomination}

\begin{tabular}{|c|c|c|c|c|c|c|}
\hline State & CCC & LCMS & NBC & PCUS & PCUSA & SBC \\
\hline Alabama & $\mathrm{X}$ & & & $\mathrm{X}$ & $\mathrm{X}$ & $\mathrm{X}$ \\
\hline Arkansas & & & & $\mathrm{X}$ & $\mathrm{X}$ & $\mathrm{X}$ \\
\hline Arizona & & & $\mathrm{X}$ & & $\mathrm{X}$ & $\mathrm{X}$ \\
\hline California & $\mathrm{X}$ & $\mathrm{X}$ & $\mathrm{X}$ & & $\mathrm{X}$ & \\
\hline Colorado & $\mathrm{X}$ & $\mathrm{X}$ & $\mathrm{X}$ & & $\mathrm{X}$ & \\
\hline Connecticut & $\mathrm{X}$ & & $\mathrm{X}$ & & $\mathrm{X}$ & \\
\hline Delaware & & & $\mathrm{X}$ & & & \\
\hline Florida & $\mathrm{X}$ & & & $\mathrm{X}$ & $\mathrm{X}$ & $\mathrm{X}$ \\
\hline Georgia & $\mathrm{X}$ & & & $\mathrm{X}$ & $\mathrm{X}$ & $\mathrm{X}$ \\
\hline Iowa & $\mathrm{X}$ & $\mathrm{X}$ & $\mathrm{X}$ & & $\mathrm{X}$ & \\
\hline Idaho & $\mathrm{X}$ & & $\mathrm{X}$ & & $\mathrm{X}$ & \\
\hline Illinois & $\mathrm{X}$ & $\mathrm{X}$ & $\mathrm{X}$ & & $\mathrm{X}$ & $\mathrm{X}$ \\
\hline Indiana & $\mathrm{X}$ & & $\mathrm{X}$ & & $\mathrm{X}$ & \\
\hline Kansas & $\mathrm{X}$ & $\mathrm{X}$ & $\mathrm{X}$ & & $\mathrm{X}$ & \\
\hline Kentucky & $\mathrm{X}$ & & & $\mathrm{X}$ & $\mathrm{X}$ & $\mathrm{X}$ \\
\hline Louisiana & $\mathrm{X}$ & & & $\mathrm{X}$ & & $\mathrm{X}$ \\
\hline Massachusetts & $\mathrm{X}$ & & $\mathrm{X}$ & & $\mathrm{X}$ & \\
\hline Maryland & & & & & $\mathrm{X}$ & $\mathrm{X}$ \\
\hline Maine & $\mathrm{X}$ & & $\mathrm{X}$ & & & \\
\hline Michigan & $\mathrm{X}$ & $\mathrm{X}$ & $\mathrm{X}$ & & $\mathrm{X}$ & \\
\hline Minnesota & $\mathrm{X}$ & $\mathrm{X}$ & $\mathrm{X}$ & & $\mathrm{X}$ & \\
\hline Missouri & $\mathrm{X}$ & $\mathrm{X}$ & & $\mathrm{X}$ & $\mathrm{X}$ & $\mathrm{X}$ \\
\hline Mississippi & & & & $\mathrm{X}$ & $\mathrm{X}$ & $\mathrm{X}$ \\
\hline Montana & $\mathrm{X}$ & & $\mathrm{X}$ & & $\mathrm{X}$ & \\
\hline North Carolina & $\mathrm{X}$ & & & $\mathrm{X}$ & $\mathrm{X}$ & $\mathrm{X}$ \\
\hline North Dakota & $\mathrm{X}$ & & $\mathrm{X}$ & & $\mathrm{X}$ & \\
\hline Nebraska & $\mathrm{X}$ & $\mathrm{X}$ & $\mathrm{X}$ & & $\mathrm{X}$ & \\
\hline New Hampshire & $\mathrm{X}$ & & $\mathrm{X}$ & & & \\
\hline New Jersey & & & $\mathrm{X}$ & & $\mathrm{X}$ & \\
\hline New Mexico & & & & & $\mathrm{X}$ & $\mathrm{X}$ \\
\hline Nevada & & & $\mathrm{X}$ & & $\mathrm{X}$ & \\
\hline New York & $\mathrm{X}$ & & $\mathrm{X}$ & & $\mathrm{X}$ & \\
\hline Ohio & $\mathrm{X}$ & & $\mathrm{X}$ & & $\mathrm{X}$ & \\
\hline Oklahoma & $\mathrm{X}$ & $\mathrm{X}$ & $\mathrm{X}$ & $\mathrm{X}$ & $\mathrm{X}$ & $\mathrm{X}$ \\
\hline Oregon & $\mathrm{X}$ & & $\mathrm{X}$ & & $\mathrm{X}$ & \\
\hline Pennsylvania & $\mathrm{X}$ & & $\mathrm{X}$ & & $\mathrm{X}$ & \\
\hline Rhode Island & $\mathrm{X}$ & & $\mathrm{X}$ & & & \\
\hline South Carolina & & & & $\mathrm{X}$ & $\mathrm{X}$ & $\mathrm{X}$ \\
\hline South Dakota & $\mathrm{X}$ & $\mathrm{X}$ & $\mathrm{X}$ & & $\mathrm{X}$ & \\
\hline Tennessee & $\mathrm{X}$ & & & $\mathrm{X}$ & $\mathrm{X}$ & $\mathrm{X}$ \\
\hline Texas & $\mathrm{X}$ & $\mathrm{X}$ & & $\mathrm{X}$ & $\mathrm{X}$ & $\mathrm{X}$ \\
\hline Utah & $\mathrm{X}$ & & $\mathrm{X}$ & & $\mathrm{X}$ & \\
\hline Virginia & & & & $\mathrm{X}$ & $\mathrm{X}$ & $\mathrm{X}$ \\
\hline Vermont & $\mathrm{X}$ & & $\mathrm{X}$ & & & \\
\hline Washington & $\mathrm{X}$ & & $\mathrm{X}$ & & $\mathrm{X}$ & \\
\hline Wisconsin & $\mathrm{X}$ & $\mathrm{X}$ & $\mathrm{X}$ & & $\mathrm{X}$ & \\
\hline West Virginia & & & $\mathrm{X}$ & $\mathrm{X}$ & $\mathrm{X}$ & \\
\hline Wyoming & $X$ & & $\mathrm{X}$ & & $\mathrm{X}$ & \\
\hline
\end{tabular}


Table 1: Basic Denomination Information

\begin{tabular}{|c|c|c|c|c|c|}
\hline Denomination & Acronym & $\begin{array}{c}\text { Rank in Size, } \\
1926 \\
\end{array}$ & $\begin{array}{l}\text { Total Members } \\
\text { in } 1930(1000 \mathrm{~s})\end{array}$ & $\begin{array}{c}\text { Average per- } \\
\text { member } \\
\text { Charitable } \\
\text { Spending } \\
\end{array}$ & $\begin{array}{c}\text { Observations in } \\
\text { Data }\end{array}$ \\
\hline Congregational-Christian Churches & CCC & 11 & 909 & 2.22 & 407 \\
\hline Lutheran Church-Missouri Synod & LCMS & 10 & 767 & 2.68 & 143 \\
\hline Northern Baptist Convention & NBC & 8 & 1434 & 2.88 & 373 \\
\hline Presbyterian Church in the United States & PCUS & 15 & 423 & 1.35 & 165 \\
\hline Presbyterian Church in the USA & PCUSA & 5 & 1929 & 3.37 & 462 \\
\hline Southern Baptist Churches & SBC & 3 & 3850 & 1.71 & 197 \\
\hline
\end{tabular}

Means are weighted by members, in year 1929 dollars. Rank data taken from 1926 Census of Religious Bodies. The unit of observation is all of a denomination's churches in a given state in a given year (for example, all the Southern Baptist Churches in Alabama in 1929 is an observation). For information on the geographic coverage of each denomination, see Appendix Table A3. 


\section{Table 2}

\section{Comparison of Denominations}

Panel A: Membership

\begin{tabular}{l|cc|cc|cc|cc} 
& & & \multicolumn{2}{c|}{} & \multicolumn{2}{c}{ Modified Churches } & \multicolumn{2}{c}{ Modified Membership } \\
& \multicolumn{2}{|c|}{ Churches (1000s) } & \multicolumn{2}{|c|}{ Membership (1000s) } & \multicolumn{2}{c}{ (1000s) } & \multicolumn{2}{c}{ (1000s) } \\
& $\mathbf{1 9 2 6}$ & $\mathbf{1 9 3 6}$ & $\mathbf{1 9 2 6}$ & $\mathbf{1 9 3 6}$ & $\mathbf{1 9 2 6}$ & $\mathbf{1 9 3 6}$ & $\mathbf{1 9 2 6}$ & $\mathbf{1 9 3 6}$ \\
\hline Our Denominations & 53 & 40 & 9,194 & 8,445 & 53 & 51 & 9,194 & 10,223 \\
All Denominations & 232 & 199 & 54,576 & 55,807 & 232 & 210 & 54,576 & 57,590
\end{tabular}

Data on membership from all denominations are taken from the 1936 Religious Census, Volume 1, Tables 23 and 26.

The "Our Denominations" data set includes the denominations listed in Table 1.

The population of the United States in 1936 and 1926 was approximately 120 million and 117 million, respectively.

The modified church and membership data in 1936 reflect the true size of the Southern Baptist Convention.

\section{Panel B: Expenditures}

\begin{tabular}{|c|c|c|c|c|c|c|c|c|}
\hline & \multicolumn{2}{|c|}{ Expenditures Per Church } & \multicolumn{2}{|c|}{$\begin{array}{c}\text { Operating Expenditures } \\
\text { Per Church }\end{array}$} & \multicolumn{2}{|c|}{$\begin{array}{c}\text { Benevolent Expenditures } \\
\text { Per Church }\end{array}$} & \multicolumn{2}{|c|}{$\begin{array}{c}\text { Modified Benevolent } \\
\text { Expenditures Per Church }\end{array}$} \\
\hline & 1926 & 1936 & 1926 & 1936 & 1926 & 1936 & 1926 & 1936 \\
\hline Our Denominations & 3,890 & 2,890 & 3,046 & 2,315 & 844 & 576 & 844 & 576 \\
\hline All Denominations & 3,783 & 2,749 & 3,088 & 2,209 & 695 & 540 & 776 & 551 \\
\hline
\end{tabular}

Data on operating and benevolent expenditures are taken from the 1936 Religious Census, Volume 1, Table 15, and the 1926 Religious Census, Volume 1 Table 15.

In some cases the sum of the expenditure breakdowns differs slightly from the total expenditures, this is due to rounding.

Modified expenditures remove spending data for the Methodist Episcopal Church and the Methodist Episcopal Church, South.

Panel C: Percentage Breakdown of Non-Operating Expenditures

\begin{tabular}{|l|c|c|c|}
\hline & Home Missions and Relief & $\begin{array}{c}\text { Foreign Missions and Spending } \\
\text { to Headquarters }\end{array}$ & Other Spending \\
\hline Our Denominations & 26 & 52 & 21 \\
\hline All Denominations & 25 & 45 & 30 \\
\hline
\end{tabular}

The table shows the percent of non-operating expenditures devoted to a given category for different groups of denominations.

Data come from the 1936 Religious Census, Volume 1, Table 15. 
Table 3:

Summary Statistics

\begin{tabular}{|l|c|c|c|c|}
\hline Variable & Mean & Std. Dev. & Min & Max \\
\hline Per-member charitable church spending & 2.63 & 1.96 & 0 & 46.33 \\
\hline Per-capita government relief spending & 10.76 & 11.47 & 0 & 46.69 \\
\hline Percent black & 13.84 & 14.31 & 0.03 & 50.44 \\
\hline Percent of 7-13 year olds attending school & 94.13 & 4.83 & 65.51 & 98.36 \\
\hline Percent of females over 15 widowed & 11.40 & 1.19 & 6.85 & 14.31 \\
\hline Farms per capita & 0.06 & 0.03 & 0 & 0.16 \\
\hline Percent foreign born & 7.27 & 7.55 & 0.26 & 25.50 \\
\hline Percent under age 18 & 35.10 & 4.74 & 24.30 & 46.20 \\
\hline Percent over 65 & 5.67 & 1.32 & 3.27 & 9.48 \\
\hline Population density & 108.06 & 125.77 & 0.79 & 671.18 \\
\hline Employment Index, 1929=100 (from Wallis, 1989) & 91.36 & 12.32 & 44.20 & 137.60 \\
\hline Per-capita personal income (1000s) & 0.53 & 0.22 & 0.16 & 1.15 \\
\hline Population (1000s) & 4349.81 & 3091.01 & 90 & 13523 \\
\hline Tenure of House members on Appropriations Committee (months) & 123.83 & 125.48 & 0 & 640 \\
\hline State percent voting democratic in last presidential election & 60.05 & 17.65 & 27 & 99 \\
\hline Churches & 1091.67 & 936.29 & 7 & 3235 \\
\hline Members (1000s) & 214.74 & 173.74 & 0.41 & 731 \\
\hline
\end{tabular}

Observations: 1747. Monetary figures in year 1929 dollars. Statistics are weighted by membership. Only one observation reports zero dollars worth of charitable church spending (the CCC in Kentucky in 1938). Public relief payments are zero before 1932; average per-capita public relief payments from 1933 to 1939 are $\$ 16.44$. The mean of per member charitable church spending from 1933 to 1939 is $\$ 2.30$. 


\section{Table 4:}

\section{Charitable Church Activity in the Great Depression}

Per-capita government relief spending
House Appropriations*Post 1932 dummy

House Appropriations

Share voting democrat in last election

Percent black

Percent of 7-13 year olds attending school

Percent of females over 15 widowed

Farms per capita

Percent foreign-born white

Percent under age 18

Percent age 65 and over

Population density

Employment index

Per-capita personal income

Churches logged

Members logged

Population logged

Region*Year Dummies?

Denomination*State Dummies?

Denomination*Year Dummies?

Observations

R-squared

Robust standard errors in brackets. Residuals are clustered at the state level. Regressions weighted by members.

Regressions include conference fixed effects, region by year dummies, and denomination by year dummies.

House Appropriations coefficient is tenure for a state's representatives who are on the Appropriations Committee.

[0.0067]
(1)

(4)

(5)

First Stage Log

$-0.0233$

First Stage

2SLS

[0.0287]

0.0124

[0.0032]

0.0003
$[0.0004]$

$-0.0042$

$-0.0081$

[0.0049]

$-0.1029$

$-0.2828$

[0.1427]

1.5369

0.0135

$-0.0779$

[0.0650]

\subsection{5}

[0.2747]

[2.0500]

9.6136

36.5739

[13.1585]

[96.4432]

$$
0.2232
$$

[0.1862]

$-2.5857$

[1.1289]

0.1473

[0.1025]

0.9205

0.3851

[0.2560]

6.7919

[1.5430]

$-0.0227$

[0.0223]

$-0.0906$

[0.2125]

0.0034

$-0.0985$

[0.0313]

0.4476

$-3.7544$

[1.0684]

[8.8588]

$-0.4016$

[0.6054]

0.8348

0.6832

[0.6183]

[1.4570]

$-4.4936$

[2.8722]

12.4442

[17.6421]

\section{Yes}

Yes

Yes

1747

Yes

Yes

Yes

1747

0.98
0.0004

[0.0001]

$-0.0017$

[0.0050]

[0.0053]

$-0.2142$

[0.1633]

0.0123

[0.0067]

0.5797

[0.2419]

10.5406

[12.3902]

0.1415

[0.1684]

0.1831

[0.0917]

0.6031

[0.3354]

$-0.0235$

[0.0192]

$-0.0008$

[0.0046]

0.1691

[1.2143]

$-0.3921$

[0.6186]

0.7238

[0.6102]

$-3.9244$

[2.5985]

Yes

Yes

Yes

1747

0.0882

[0.1277]

$-0.018$

[0.0052]

[0.2099]

3.4385

[8.7527]

0.0188

[0.0799]

$-0.0052$

[0.0519]

0.353

[0.1258]

$-0.0076$

[0.0144]

$-0.0009$

[0.0037]

$-0.2809$

[0.6491]

$-0.2068$

[0.1740]

0.0484

[0.0953]

$-1.2317$

[1.4630]

Yes

Yes

Yes

1110

0.98
$-0.0785$
$-0.0011$

2SLS Log Log $-0.7699$ [0.4278]

[0.0061]

0.099

[0.1383]

$-0.0124$

[0.0083]

$-0.2204$

[0.2118]

9.4212

[8.2988]

$-0.0316$

[0.0647]

$-0.0478$

[0.0515]

0.4125

[0.2460]

$-0.0427$

[0.0150]

0.0007

[0.0028]

$-0.0162$

[0.5293]

0.5931

[0.4489]

$-0.0061$

[0.2608]

$-0.6701$

[1.3846]

Yes

Yes

Yes

1110 
Table 5:

Sensitivity to Denomination

\begin{tabular}{lcccccc}
\hline & No CCC & No LCMS & No NBC & No PCUS & No PCUSA & No SBC \\
\hline Per-capita government relief spending & -0.0672 & -0.0609 & -0.0512 & -0.0534 & -0.041 & -0.0697 \\
& {$[0.0355]$} & {$[0.0365]$} & {$[0.0360]$} & {$[0.0274]$} & {$[0.0310]$} & {$[0.0364]$} \\
Region*Year Dummies? & Yes & Yes & Yes & Yes & Yes & Yes \\
Denomination*State Dummies? & Yes & Yes & Yes & Yes & Yes & Yes \\
Denomination*Year Dummies? & Yes & Yes & Yes & Yes & Yes & Yes \\
Includes All Regressors? & Yes & Yes & Yes & Yes & Yes & Yes \\
Observations & 1340 & 1604 & 1374 & 1582 & 1285 & 1550 \\
\hline
\end{tabular}

Robust standard errors in brackets. Residuals are clustered at the state level. Regressions weighted by members.

These regressions include all of the controls used in Table 4. See notes to Table 4 for more details. 


\section{Table 6: Robustness Checks}

\begin{tabular}{|c|c|c|c|c|c|c|}
\hline & $\begin{array}{l}\qquad(1) \\
\text { On Operating } \\
\text { Expenses } \\
\end{array}$ & $\begin{array}{c}\text { Religious } \\
\text { Census }\end{array}$ & $\begin{array}{c}\text { Religious } \\
\text { Census }\end{array}$ & $\begin{array}{l}\text { (4) } \\
\text { First Stage } \\
\text { w/Debt } \\
\text { Instrument } \\
\end{array}$ & $\begin{array}{c}\text { 2SLS w/Debt } \\
\text { Instrument }\end{array}$ & $\begin{array}{c}(6) \\
\text { 2SLS w/Debt \& } \\
\text { House } \\
\text { Instruments }\end{array}$ \\
\hline Per-capita government relief spending & $\begin{array}{c}0.2073 \\
{[0.2089]}\end{array}$ & $\begin{array}{c}-0.0381 \\
{[0.0277]}\end{array}$ & $\begin{array}{c}-0.0442 \\
{[0.0174]}\end{array}$ & & $\begin{array}{c}-0.1238 \\
{[0.0427]}\end{array}$ & $\begin{array}{c}-0.0835 \\
{[0.0300]}\end{array}$ \\
\hline Debt constraint dummy*Post 1932 dummy & & & & $\begin{array}{c}-2.581 \\
{[1.0456]}\end{array}$ & & \\
\hline State Dummies? & No & Yes & Yes & No & No & No \\
\hline Year Dummy? & No & No & Yes & No & No & No \\
\hline Region*Year Dummies? & Yes & Yes & No & Yes & Yes & Yes \\
\hline Denomination*State Dummies? & Yes & No & No & Yes & Yes & Yes \\
\hline Denomination*Year Dummies? & Yes & No & No & Yes & Yes & Yes \\
\hline Includes All Regressors? & Yes & Yes $^{\dagger}$ & Yes $^{\dagger}$ & Yes & Yes & Yes \\
\hline Observations & 1747 & 96 & 96 & 1747 & 1747 & 1747 \\
\hline
\end{tabular}

Robust standard errors in brackets. Regressions weighted by members.

Overidentification test for the regression using both instruments: (Chi-squared with one degree of freedom): $1.035, p=0.309$

${ }^{\dagger}$ Data on employment and personal income are not available in 1926 and are excluded for these regressions.

These regressions include all of the controls used in Table 4, except as noted. See notes to Table 4 for more details. 


\section{Table 7: State Summary Statistics by Debt Limit: 1929-1933}

\begin{tabular}{lcc}
\hline & Limit & No Limit \\
\hline Share voting democratic & 45.51 & 45.63 \\
& {$[14.17]$} & {$[11.08]$} \\
Percent black & 12.84 & 14.84 \\
& {$[13.99]$} & {$[15.28]$} \\
Percent 7-13 year olds in school & 94.23 & 94.29 \\
Percent females over 15 widowed & {$[4.09]$} & {$[3.79]$} \\
Farms per capita & 11.26 & 11.19 \\
& {$[1.41]$} & {$[0.95]$} \\
Percent foreign born & 0.06 & 0.07 \\
Percent under 18 & {$[0.03]$} & {$[0.04]$} \\
& 8.27 & 7.78 \\
Percent over 65 & {$[8.04]$} & {$[8.41]$} \\
Population density & 36.22 & 36.99 \\
Eotal Observations & {$[4.44]$} & {$[4.82]$} \\
Employment index & 5.17 & 5.31 \\
& {$[1.20]$} & {$[1.23]$} \\
& 100.60 & 121.20 \\
& {$[123.54]$} & {$[130.50]$} \\
& 90.01 & 87.66 \\
& {$[9.38]$} & {$[10.70]$} \\
& 0.54 & 0.49 \\
& {$[0.23]$} & {$[0.24]$} \\
& 408 & 228 \\
\hline
\end{tabular}

Standard deviations in brackets. Means are weighted by membership. 
Figure 1: Government and Church Relief during the Great Depression

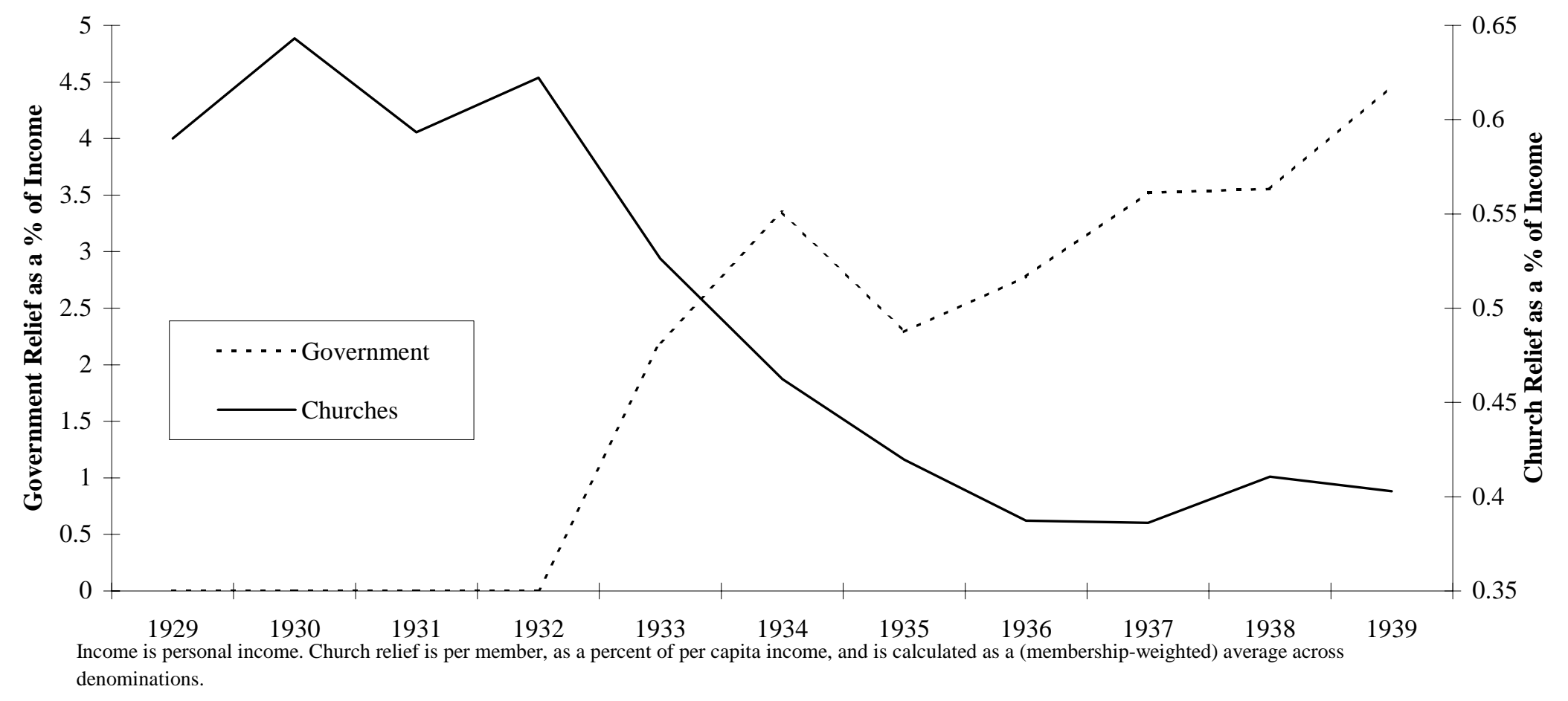


Figure 2: State Limits on Financing Relief with Debt

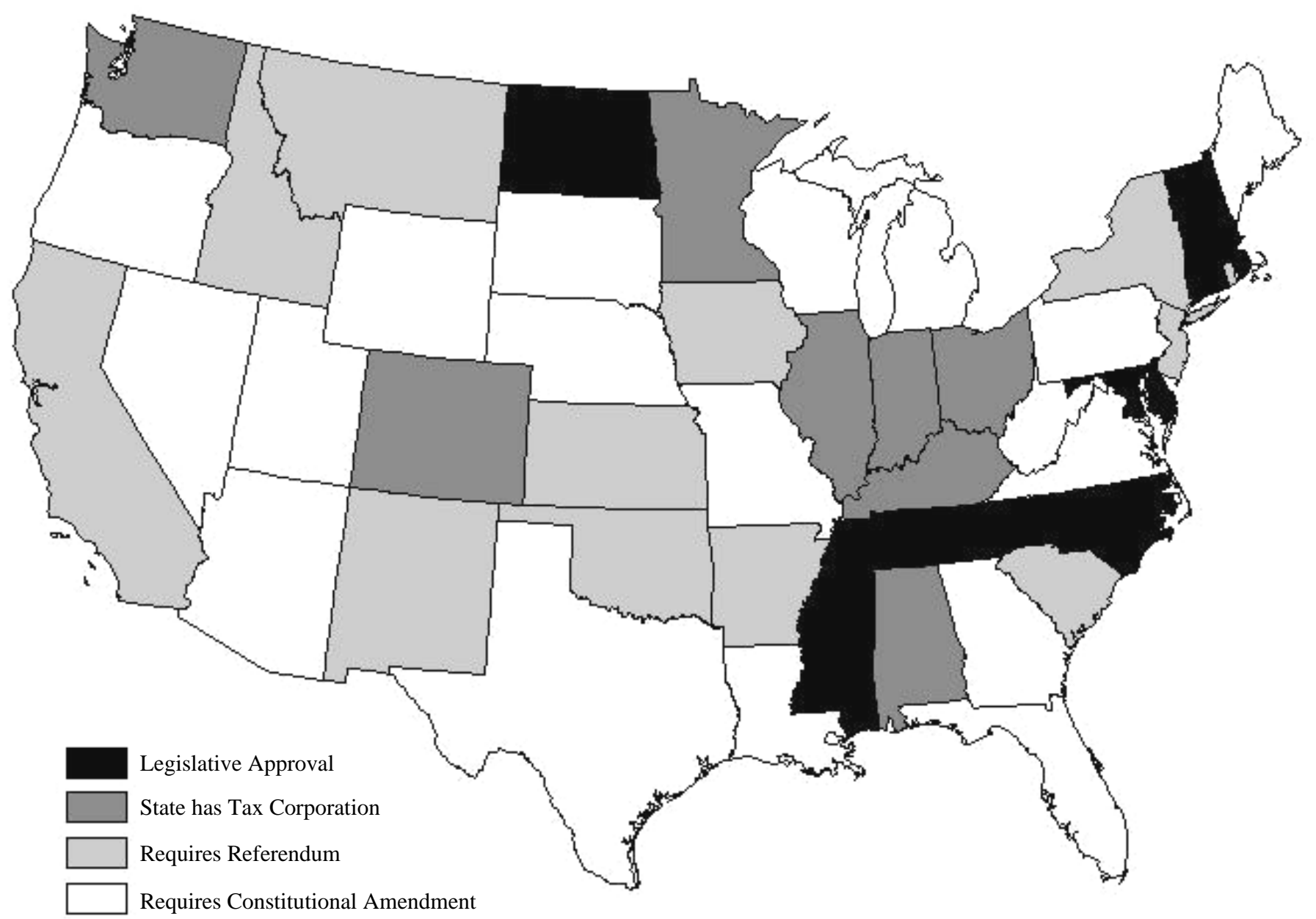

